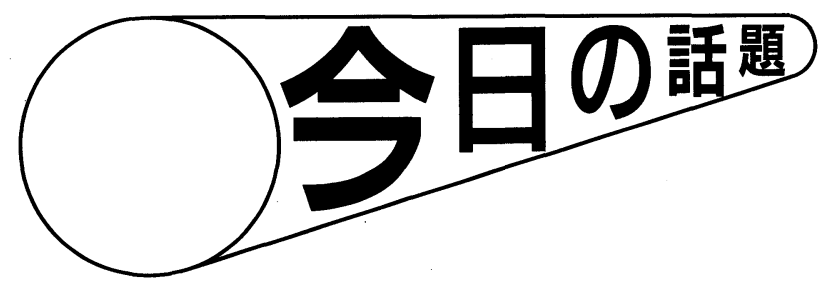

\title{
ヒト膵液に含まれるホスホリパーゼ $\mathrm{A}_{2}$ は膵癌細胞の増殖を促進する その発見亡分子メカニズム
}

近年，わが国において膵臓癌の発生する頻度は年々増 加の一途をたどっている. 平成 6 年に発表された厚生省 大臣官房統計情報部の人口動態統計によると, 膵㵴癌に よる死亡率は 12.1 (人口 10 万対)であった。この数字は すべての癌の死亡率の中で第 7 位を占めている，米国で も，全癌死亡例の中で膵臟癌によるものは第 4 位であ り,この癌に侵されて 1 年を越える生存率は $12 \%$ に満 たないという．このように，膵蔵癌の死亡率が高い理由 のひとつとして, その癌の早期発見がきわめて難しいこ とが挙げられる，というのは，膵蔵は後腹膜腔の奥深く にあり, かつ扁平な形をしているため, 触診が難しいこ と, それに加えて, 発症の初期においては自覚症状が他 の上腹部疾患と区別しにくいのも膵臟癌を見逃す一因と なろう。では, 膵蔵癌が消化器系癌の中でも特に悪性度 が高く, 予後の不良な癌であるという事実を, 膵蔵の位 置する解剖学的見知からのみ理解してよいのだろうか.

最近になって, 本来は生体内において特定の消化器官 の運動や消化液の分泌を制御するはずのガストリンやコ レシストキニンなどの消化管ホルモンが, 膵臟癌の増殖 に関わっているという発表がなされた(1).さらに, 興味深 いことに, 筆者ら ${ }^{(2)}$ はヒト膵液中に含まれる消化酵素ホ スホリパーゼ $\mathrm{A}_{2}\left(\mathrm{PLA}_{2} ; \mathrm{EC}\right.$ 3.1.1.4) が，膵癌細胞の 増殖を促進する現象を発見したのである。

$\mathrm{PLA}_{2}$ は，グリセロリン脂質のグリセロール 2 位の脂 肪酸エステル結合を加水分解する酵素の総称であり, そ
の触媒活性の発現には $\mathrm{Ca}^{2+}$ の存在が必須である．本酵 素は, 膵液中の他, 炎症性細胞やへビ毒および八チ毒中 にも存在し，分子量やアミノ酸配列の違いなどにより， I， II，III型の PLA P $_{2}$ よび高分子量細胞質内在型夕イ プ $\mathrm{PLA}_{2}\left(\mathrm{cPLA}_{2}\right)$ に分類されている(3). その生理機能と しては，生体膜リン脂質の生合成や代謝に関わるものが ある他，アラキドン酸遊離のトリガー酵素としても機能 する $\mathrm{PLA}_{2}$ (ヒト II 型 PLA $\mathrm{PLC}_{2} \mathrm{PLA}_{2}$ ) があり，今や $\mathrm{PLA}_{2}$ は各種疾患との関連で興味の対象となっている.

ヒト膵液に含まれる $\mathrm{PLA}_{2}$ は分子量 $14 \mathrm{kDa}$ の分泌酵 素であり，I 型に分類されている，この I 型ヒトホスホ リパーゼ $\mathrm{A}_{2}(\mathrm{hPLA}-\mathrm{I}$ と略) は膵臓でつくられ，まず酵 素活性を有しない前駆体型酵素として膵腺房細胞から膵 液中へ分泌される，膵臓では，トリプシンの前駆体，す なわちトリプシノーゲンも生合成されており，膵液の一 成分として十二指腸に分泌された後，十二指腸粘膜に存 在するエンテロキナーゼの作用でトリプシンに変換され る.膵液中に分泌された前駆体 $\mathrm{hPLA}-\mathrm{I}$ は, トリプシン によって $\mathrm{N}$ 末端から 7 つのアミノ酸が切除されること により, 成熟型 $\mathrm{PLA}_{2}$ に変換されるのである.

これまで, 成熟型 $\mathrm{hPLA}-\mathrm{I}$ は, 主に, 食物中に含まれ るリン脂質を消化するために存在するものと考えられて きた。ところが, 近年の分子生物学の発展に伴って, $\mathrm{hPLA}{ }_{2}-\mathrm{I}$ が膵㵴以外, たとえば, 肺や脾臟などの非消化 器官でも作られていることがわかってきた ${ }^{(4,5)}$. この事実 
は, hPLA 2 -I の生理機能を単に食物消化のみに限定す心゙ きではないことを示唆している.

筆者らは, MIAPaCa-2 と命名された膵癌細胞に hPLA 2 -I を加えると, その癌細胞の増殖が促進される 現象を発見した．さらに，この膵癌細胞には hPLA $-\mathrm{I}$ のための特異的レセプターの存在することを見いだし た ${ }^{(2)}$. Scatchard plot 解析から，本レセプターは単一で あり, 解離定数は $\mathrm{nM}$ オーダーであることがわかった. それらに加えて, $\mathrm{Ca}^{2+}$ キレート剤である EDTA 存在下 においてさえも $\left[{ }^{125} \mathrm{I}\right]-\mathrm{hPLA} \mathrm{A}_{2}-\mathrm{I}$ の特異的結合が認めら れること； $\mathrm{PLA}_{2}$ による酵素消化物すなわちリゾリン脂 質には MIAPaCa-2 に対する増殖効果がないこと; MIAPaCa- 2 に高濃度の hPLA - I を添加しても, $\mathrm{hPLA}_{2}-\mathrm{I}$ の直接的な作用による生体膜からの脂肪酸の 遊離は起こらないことなどを明らかにした。これらの結 果から, hPLA 2 -I によって誘導される膵癌細胞の増殖促 進作用は, $\mathrm{hPLA}-\mathrm{I}$ の消化酵素としての活性を介する反 応ではなく, hPLA $-\mathrm{I}$ の特異的レセプターを介したもの であると結論づけた ${ }^{(6)}$. 興味深いことに，このような膵 癌細胞に対する増殖促進作用は蜂毒や蛇毒由来の $\mathrm{PLA}_{2}$ はもちろんのこと, 前駆体型 $\mathrm{hPLA}-\mathrm{I}$ でさえ認められ なかった.すなわち, 成熟型 $\mathrm{hPLA}-\mathrm{I}$ が特異的に膵癌細 胞の増殖を促進したのである.

$\mathrm{hPLA}_{2}-\mathrm{I}$ によるこの增殖促進作用を分子レベルで明 らかにするにあたって, 膵癌細胞株に hPLA 2 -I の特異 的レセプターが存在するという事実は, リガンドである $\mathrm{hPLA}_{2}-\mathrm{I}$ がレセプターに結合後, 何らかの細胞内シグナ ル伝達機構のスイッチが入ることを示すものと考えられ る.そこで, そのシグナル伝達経路を解明するため, ま ず，アラキドン酸カスケードの関与について調査した. 具体的には, MIAPaCa-2 細胞の生体膜に $\left[{ }^{3} \mathrm{H}\right]$ 標識のア ラキドン酸を代謝標識後, hPLA 2 -I を添加することによ り，[ $\left.{ }^{3} \mathrm{H}\right]$ アラキドン酸およびその代謝産物の放出が誘導 されるか否か調べたのである。その結果, $\mathrm{hPLA}_{2}-\mathrm{I}$ を添 加して培養すると, 培養上清中にアラキドン酸およびそ の代謝産物の有意な放出が認められた。ただし，この放 出作用は, 48 時間培養後の遅延的な細胞応答であったこ とから, hPLA 2 -I の直接的な酵素触媒作用によるもので はなく，何か別のシグナル伝達カスケードを介した誘導 作用であると推定された。

次に, $\mathrm{hPLA}_{2}-\mathrm{I}$ の膵癌細胞増殖促進作用と細胞分裂 促進タンパク質キナーゼ (mitogen-activated protein

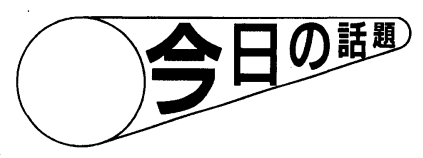

kinase：MAPK) カスケードとの関連性を調べた結果, $\mathrm{hPLA}_{2}-\mathrm{I}$ の添加後, MAPK キナーゼ $(\mathrm{MAPKK}) \rightarrow$ $\mathrm{MAPK} \rightarrow \mathrm{ATF}-2$ といった連鎖的なりン酸化反応が認 められた。このように, hPLA 2 -I による膵癌細胞増殖促 進作用が, 少なくとも 2 つ細胞内シグナル伝達経路を 介している可能性が示唆された。そこで, それぞれの経 路の選択的阻害剤を用いて, hPLA $2-\mathrm{I}$ が与える膵癌細胞 増殖促進効果への影響を調べた結果, アラキドン酸代謝 酵素の阻害剤の indomethacin や nordihydroguaiaretic acid ではなく, MAPKK の選択的リン酸化阻害剤で

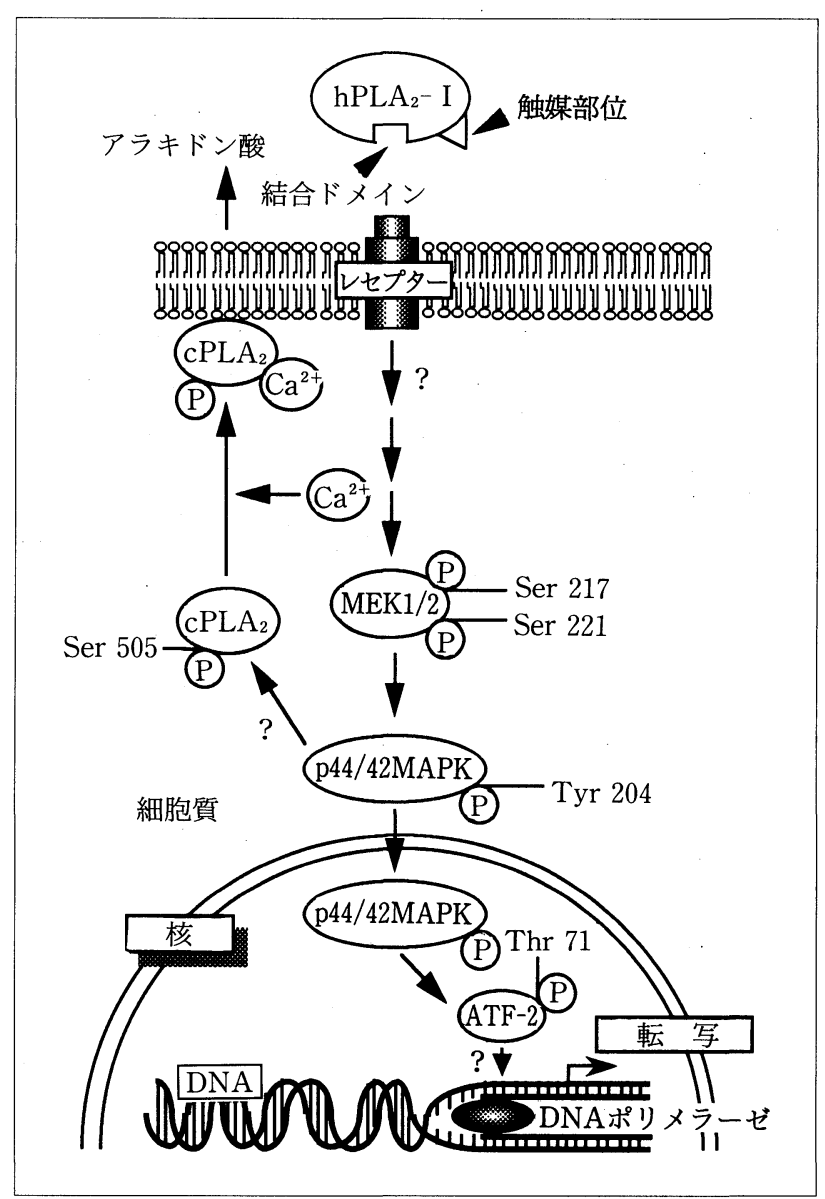

図 1 『膵癌細胞株 $(\mathrm{MIAPaCa}-2)$ における hPLA $-\mathrm{I}$ の作用 動態モデル

$\mathrm{hPLA}_{2}-\mathrm{I}$ には酵素触媒部位とレセプター結合部位がそれぞれ独立 に存在することが予想される。また MIAPaCa-2の生体膜には hPLA $-\mathrm{I}$ に対する特異的なレセプターが存在する. hPLA 2 -I が MIAPaCa-2 の有する特異的レセプターに結合すると, hPLA $-\mathrm{I}$ の值接的な作用による脂肪酸の放出は起こらず(間接的な作用によ るアラキドン酸の放出は誘導する)，MAPK カスケードを介した シグナルが核へと伝達されて細胞増殖をひき起こす。

$\mathrm{cPLA}_{2}$ : 高分子量細胞質内在型 $\mathrm{PLA}_{2}, \mathrm{Ser}$ ：セリン, Tyr : チロシ ン, Thr:スレオニン 
ある PD98059 を加えた場合に, hPLA - I 誘導型細胞増 殖促進作用の阻害が観察されたのである。すなわち， $\mathrm{hPLA}_{2}-\mathrm{I}$ によって誘導される膵癌細胞増殖促進作用は, アラキドン酸カスケードを介した反応ではなく, MAPK カスケードを介したものと言える(7) (図 1).

筆者らは, 膵頭十二指腸切除手術を受けた患者の膵管 ドレナージチューブから得られた大量の膵液を材料に, hPLA 2 -I を単一蛋白質として精製した。この $\mathrm{PLA}_{2}-\mathrm{I}$ のN末端から 20 アミノ酸までの配列は, 成熟型 $\mathrm{hPLA}_{2}-$ I のそれと $100 \%$ 一致した ${ }^{(2)}$.すなわち，ヒト膵液中には 成熟型 $\mathrm{PLA}_{2}-\mathrm{I}$ が存在することを示している.

膵臟癌が, 消化器系癌の中でも特に悪性度が高く, 予 後の不良な癌である要因のひとつとして, 『萃管に生じ た膵臓癌が原因で, 膵液が流出障害を起こし, その結果 として, 膵液中の $\mathrm{hPLA}-\mathrm{I}$ が多量に溜まり, それがさら なる膵臓癌の増殖を促すのではないか』という考えを筆 者らはもってきた。本結果はこの仮説を強く支持するも のである.さらに, $\mathrm{hPLA}_{2}-\mathrm{I}$ には膵癌細胞増殖促進作用 以外に，アラキドン酸およびその代謝産物を遊離させる 作用を備えていることがわかってきた。このことは, 膵 臟癌の増殖と炎症性疾患（膵炎）との間には密接な関連 性があることを示すものであり，本知見は今後の膵臓癌 を診断・治療する上で大変意義深いものと思われる.

本研究を通して, $\mathrm{hPLA}_{2}-\mathrm{I}$ の膵癌細胞増殖作用が本来 の酵素触媒反応とは異なった生理作用であることを証明 したが，この点について少々触れてみよう．酵素をリガ ンドとして，それを感知するレセプター（あるいは生体 膜上の結合蛋白質）の存在することはこれまでにも報告 されてきた。だが，それらの例のほとんどは，レセプタ 一への結合後にその酵素活性の発現が必ず認められるの である。ある場合には，リガンドの酵素活性を発現させ る場所を特定させるためにレセプターが存在し，別の例
では，レセプター結合後に，リガンド自身の酵素活性を 用いてレセプターの特定領域が切断されることもある. しかしながら，レセプターへの hPLA $\mathrm{PLI}_{2}$ 結合後に誘起 されるシグナルの伝達にあたっては, 必ずしも hPLA $\mathrm{A}_{2}-\mathrm{I}$ の酵素機能を必要としない。それでは，なぜ，酵素触媒 機能をもったタンパク質（ここでは $\mathrm{hPLA}_{2}-\mathrm{I}$ のこと）を 細胞内シグナル伝達のためのリガンドとして用いる必要 性があるのであろうか？ 残念ながら，この解答を得る ための実験成果は未だ得られていない.

これまで述べてきたように，筆者らは, hPLA 2 -I の膵 癌細胞増殖作用が正常細胞にも普遍的に存在する MAPK カスケードを介していることを明らかにした。 このことは，言い換えれば，膵臓癌の増殖抑制を目的と した薬を開発する場合，MAPKカスケードの選択的阻 害剂を利用するわけにはいかないことを示している，以 上のことから考えると, 最終的には, 脂質分解酵素活性 は抑制せず，細胞増殖活性のみを抑制する hPLA 2 -I 阻 害物質，たとえば，レセプターへの結合のみを選択的に 阻害するレセプター・アンタゴニストのような薬剤を探 索・開発することが, 膵藏癌の増殖の抑制を目的とした 医薬品の開発へとつながる最良の道であり, かつ期待さ れるところであろう。

1) J.P. Smith, A. Shih, Y. Wu, P.J. McLaughlin \& I.S. Zagon: Am. J. Physiol., 270, 1078 (1996).

2) K. Hanada, E. Kinoshita, M. Itoh, M. Hirata, G. Kajiyama \& M. Sugiyama: FEBS Lett., 373, 85 (1995).

3) 工藤一郎, 井上圭三 : 生化学, 64, 1330 (1992).

4) T. Sakata et al. : Biochim. Biophys. Acta, 1007, 124 (1989).

5) H. Tojo, T. Ono, S. Kuramitsu, H. Kagamiyama \& M. Okamoto : J. Biol. Chem., 263, 5724 (1988).

6) E. Kinoshita, K. Hanada, M. Itoh, T. Kumagai, G. Kajiyama \& M. Sugiyama: Int. J. Oncol., 9, 1219 (1996).

7) E. Kinoshita, N. Handa, K. Hanada, G. Kajiyama \& M. Sugiyama : FEBS Lett., in press.

(木下英司, 杉山政則, 広島大学医学部)

\section{植物の篩管中に存在するタンパク質の機能とその由来 高分子物質は細胞間をどのように移動するか}

「植物のからだには導管と篩管とからなる通道組織が あって, 導管は根から吸収された水を運び, 篩管は光合 成によって作られた糖などの養分を運ぶ管である」.こ う教えられたのは, 確か小学生の頃だったように記憶し
ている，本誌の読者ならば，誰でもこの導管と篩管とい う名前を一度は耳にしたことがあるのではないだろう か.

導管は死細胞の細胞壁からなる管であるのに対し，篩 

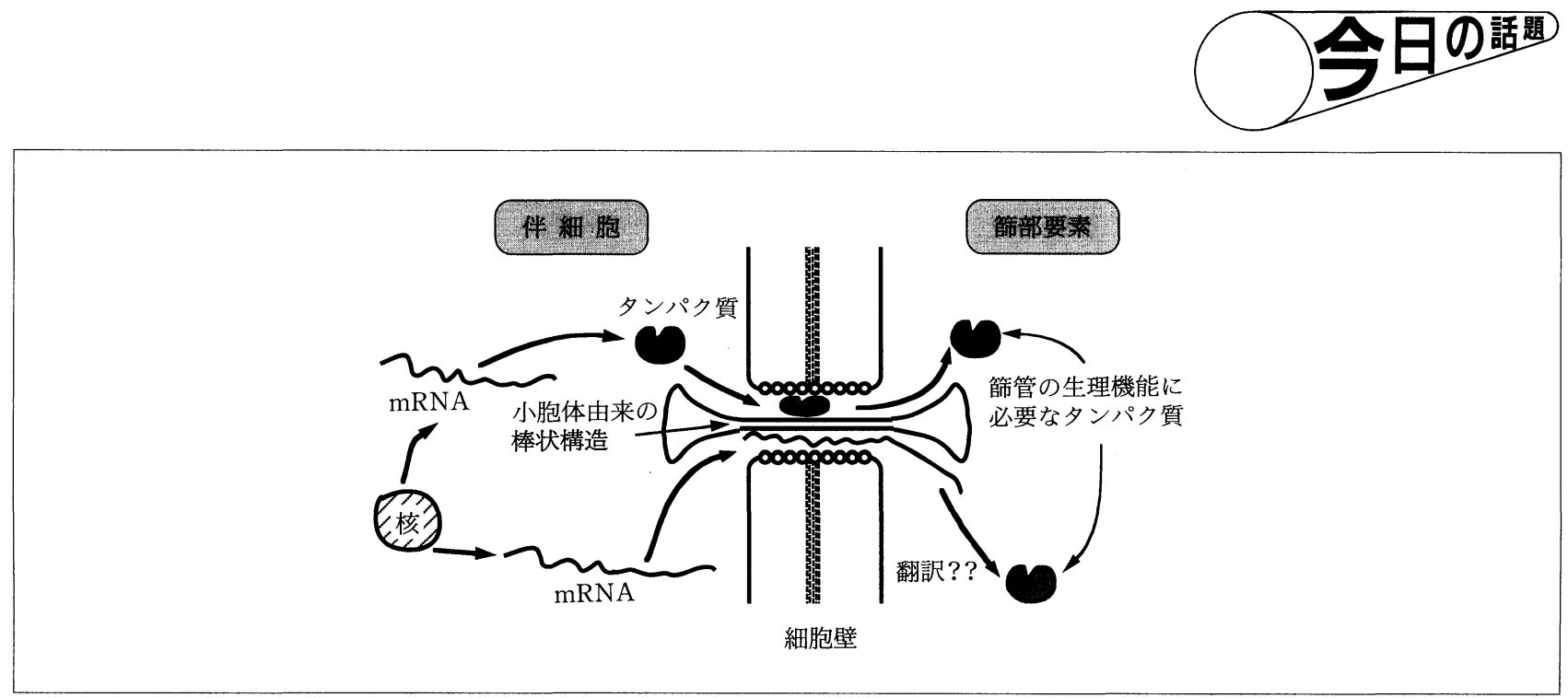

図 1 -伴細胞-篩部要素間の原形質連絡を通じた高分子物質移動のスキーム(文献(6)より改変)

管は篩部要素と呼ばれる生細胞の連なりからなる組織で ある，上下に並ぶ篩部要素間では，ふるい状に穴の開い た篩板を介して細胞質が連絡し，篩管を形成することが わかっている，顕微鏡による観察では，篩部要素は成熟 過程において核や小胞体上のリボソームを失うことか ら，タンパク質の合成能をもたないと考えられている. こうした個々の篩部要素には伴細胞と呼ばれる代謝の活 発な細胞が隣接し，両者の間には特殊な形状の原形質連 絡が密に存在するが，この 2 種類の細胞と周囲の細胞と の間では原形質連絡の密度が低いことが知られている.

篩管を通しての養分の転流を研究する際には, 篩管液 を採取して，含まれている物質を分析する方法がとられ てきた、今までに篩管液中には無機イオンや糖，アミノ 酸といった低分子物質から，タンパク質や核酸といった ような高分子物質までが含まれることが示されてい $る^{(1)}$.ここでは,このうち篩管液タンパク質についての最 近の研究について紹介する.

筆者らの研究室では, トビイロウンカを用いたインセ クトレーザー法*によってイネから篩管液を採取し，分 析してきた。こうして得られるイネ篩管液中には, 約 0.2 $\mathrm{mg} / \mathrm{ml}$ の濃度でタンパク質が含まれている(2).イネ篩管 液中のタンパク質を 2 次元電気泳動によって分離し，銀 染色すると，分子量数千から 6 万まで，200 個以上のス ポットが確認される ${ }^{(2)}$. 筆者らは，このうち存在量の多 いタンパク質の 1 つである $13 \mathrm{kDa}$ のタンパク質を，部 分アミノ酸配列の決定, cDNA の単離と塩基配列の決定

*篩管液を吸汁中の昆虫の口針を YAGレーザー光により切断し， その切り口からあふれ出る液を採取する方法
などにより，チオレドキシン $h$ と同定した ${ }^{(3)}$.

チオレドキシンはすべての生物細胞に存在する大きさ 約 10 数 $\mathrm{kDa}$ のタンパク質で，チオレドキシン還元酵素 によって活性化され，チオール基還元活性をもつタンパ ク質である.したがって，篩管の中で何らかの標的酵素 の活性調節を行なったり，酸化的ダメージを受けたタン パク質の修復をこの篩管チオレドキシン $h$ が行なって いることが予想される。実際に，ヒマ（Ricinus communis L.) の篩管液中にはグルタレドキシンが多く存在 することが確認されていること(4) を考えると，篩管中に はチオール基の還元システムの存在が重要であると推測 される.さらに, 熱ショックタンパク質 HSP70, シャペ ロニン GroEL，ユビキチンといったタンパク質の存在 が示唆されていることから ${ }^{(5)}$ ，それ自身では新たにタン パク質を合成できない篩管中において，これらの分子が タンパク質の構造安定化に働いていると思われる。

このように，篩管の中には様々なタンパク質が存在す るが，核や機能するリボソームをもたない細胞の中に， どのようにしてタンパク質が存在するようになるのか, という点は疑問である。一つの可能性として，これらは 隣接する細胞（おそらく伴細胞）で合成され，原形質連 絡を通って篩部要素に移行すると考える仮説があるが, この原形質連絡を通過できる物質の大きさには限界があ ること（この值を Size Exclusion Limit：略称 SEL) が

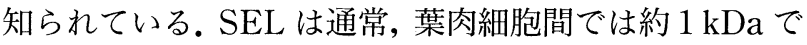
あり ${ }^{(6)}$ ，現在までに報告されている SEL の中で一番大 きいものでも $10 \mathrm{kDa}$ である(7).その一方で，SEL を超 えた大きさのタンパク質が細胞間を移動する現象が植物 
ウイルスの移動タンパク質やいくつかの転写因子につい て観察されている(8). また,これまでに筆者らは, 篩管チ オレドキシン $h$ が原形質連絡を通じて細胞間を移行す ることを示す結果を得ていることから, 篩管中のタンパ ク質は近隣の細胞から細胞間を移行してくる可能性が高 い.

一方で最近, mRNA が篩管に移行することを示唆す る実験結果が報告された，Kühn らは, 篩管における養 分転流に重要な役割をもつと思われるタンパク質, シュ ークローストランスポーター (SUT1) が篩部要素の細胞 膜上に局在しており，このタンパク質をコードしている mRNA は篩部要素と伴細胞とに（特に両者の間の原形 質連絡に)それぞれ存在することを示した ${ }^{(9)}$. SUT1 タン パク質, mRNA はともに分解, 合成速度が速いことか ら, 篩部要素の分化の過程の残存物ではなく, 篩部要素 と伴細胞とにおいて新規に合成されていると推測され る.したがって, この mRNAの移行によって SUT1 夕 ンパク質が篩管に存在するようになる可能性が考えられ る.

複数の細胞から構成される高等生物において, タンパ ク質や mRNA の細胞間移行に関する報告例はあまり多 くない.今回述べた高等植物に限って考えてみると,こ

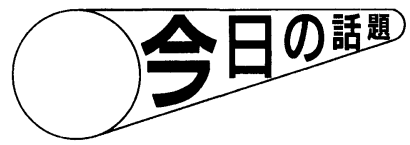

ういった特殊な機構が，進化に伴って発達してきた通導 組織の機能を維持するために採用されている可能性は高 い. 今後のこの分野の研究のさらなる進展によって, 夕 ンパク質や mRNAの細胞間移行の機構のみならず，篩 部要素という特殊な細胞の性質が解明されることが期待 される。

1) W. Eschrich \& W. Heyser : Encyclopedia of Plant Physiology, 1, 101 (1975).

2) S. Nakamura, H. Hayashi, S. Mori \& M. Chino : Plant Cell Physiol., 34, 927 (1993).

3) Y. Ishiwatari, C. Honda, I. Kawashima, S. Nakamura, H. Hirano, S. Mori, T. Fujiwara, H. Hayashi \& M. Chino: Planta, 195, 456 (1995).

4) C. Schobert, P. Grossmann, M. Gottschalk \& J. Szederkenyi : J. Exp. Bot., 47, 1298 (1996).

5) C. Schobert, P. Grossmann, M. Gottschalk, E. Komor, A. Pecsvaradi \& U.Z. Nieden: Planta, 196, 205 (1995).

6) W. J. Lucas, B. Ding \& C. van der Schoot: New Phytol., 125, 435 (1993).

7) R. Kempers, J.K. van Amerongen, J. Achterberg \& A.J. E. van Bel : J. Exp. Bot., 47, 1298 (1996).

8) W. J. Lucas, S. Bouche-Pillon, D.P. Jackson, L. Nguyen, L. Baker, B. Ding \& S. Hake : Science, 270, 1980 (1995).

9) C. Kühn, V.R. Franceschi, A. Schulz, R. Lemoine \& W.B. Frommer: Science, 275, 1298 (1997).

(石渡 裕, 林 浩昭, 藤原 徹, 茅野充男, 東京大学大 学院農学生命科学研究科)

\section{動物(ホヤ)で初めて観察されたセルロース合成醭素複合体 被のうに接した表皮細胞膜に局在}

セルロースは地球上で最も豊富な天然高分子であり, そのほとんどは植物, 特に樹木により生産されている. また植物以外でもバクテリア, 菌類, 粘菌類のほか動物 でもセルロースを作り出す生物が知られており, セルロ 一スの合成能は生物界に広く分布している(1).一般に, 陸上植物や藻類などでは細胞の原形質膜に埋め込まれた 合成酵素複合体（電顕で観察されるセルロース合成装置 で, terminal complexes=TCs と呼ばれる)でセルロー スを直接, 合成・結晶化してミクロフィブリルの形で細 胞外へと放出し, 細胞壁の主成分として植物体の形づく りに役立てている．また，TCs を構成する膜顆粒の数や 配列は生物種により異なっており, それがセルロースミ クロフィブリルの太さや結晶性の違いを左右する要因の 一つとして指摘されている(2).
これまで, 陸上植物や藻類を含む数多くの植物で TCs の形状が調べられ, 藻類ではきわめて多様な TCs の形 状がみられることが判明している ${ }^{(3)}$.さらに, これら多様 な TCs の形状を有する藻類のうち, 淡水性の車軸藻と 高等植物とがきわめて近縁であることを伺わせるような TCs の形状の一致がみられている(3).

このように,生物の分類群の間で TCs の形状の類似性 を調べることにより，七ルロース生合成の進化の足どり をたどることができる，そこで，セルロース生合成の仕 組みについてはほとんど解明されておらず，かつ分類群 が大きく隔たり, 動物の仲間で唯一七ルロースを生産す るホヤについて研究を進めたところ, 筆者らは最近, 動 物（ホヤ）で初めて新しい種類の TCs の観察に成功し た ${ }^{(4)}$. その結果, 生物によるセルロース合成は植物, 動物 


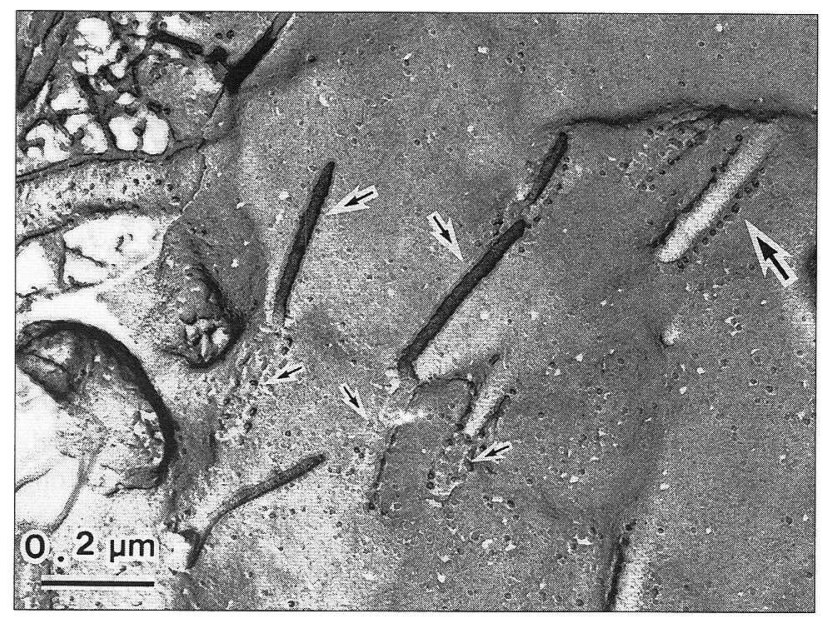

図 1 -ホヤの表皮細胞の被のう側細胞膜の凍結割断像

ホヤの TCs は細長い直線型で, 細胞側へ深く篗んでいる(大矢印). しばしばTCsの筀みにはアモルファス状物質が充填されており (小矢印)，そこから連続して伸長するミクロフィブリルが観察され る (中矢印)。

を問わず普遍的に TCsで行なわれることが明らかとな った。このように，植物とは系統のかけ離れたホやの TCsの構造が明らかになったことは, 前述の TCsの形 状とセルロースミクロフィブリルの結晶化機構との関係 を明らかにする大きな手がかりを与えてくれている。

すでに，ホヤでは被のう（ホヤの外皮組織でセルロー スを含む）以外に表皮細胞が特殊に分化したグロメルロ サイトという細胞の液胞内でミクロフィブリルの束が形 成されることを筆者らは報告している(5,6) が, 今回, ホヤ の被のうのセルロース合成に関わる TCs の構造やその 局在部位について説明し，あわせて他の生物の TCs と合 成されるセルロースミクロフィブリルの形態との関係に ついても言及したい。

通常，TCs は原形質膜に埋め込まれているため，それ を可視化するには凍結割断レプリカ法が現在最も有力な 手段である。図 1 が今回観察されたホヤ（ウエダイトヒ キボヤ Metandrocarpa uedai）の TCsの凍結割断レプ リカの電顕像である。ホヤの TCs は表皮細胞の被のう に面した原形質膜上でのみみられ，タイトジャンクショ ン*を境に表皮細胞の側面の細胞膜上ではいっさい観察 されない。このことは，表皮細胞で生産されるセルロー スがホヤの被のうへのみ分泌されることと一致する。ホ ヤの TCs は全長約 $200 \mathrm{~nm}$ で, 細胞膜上を移動できる

*細胞間結合の一種で，隣接する細胞の細胞膜結合部位にみられる 目張り系様の網目構造

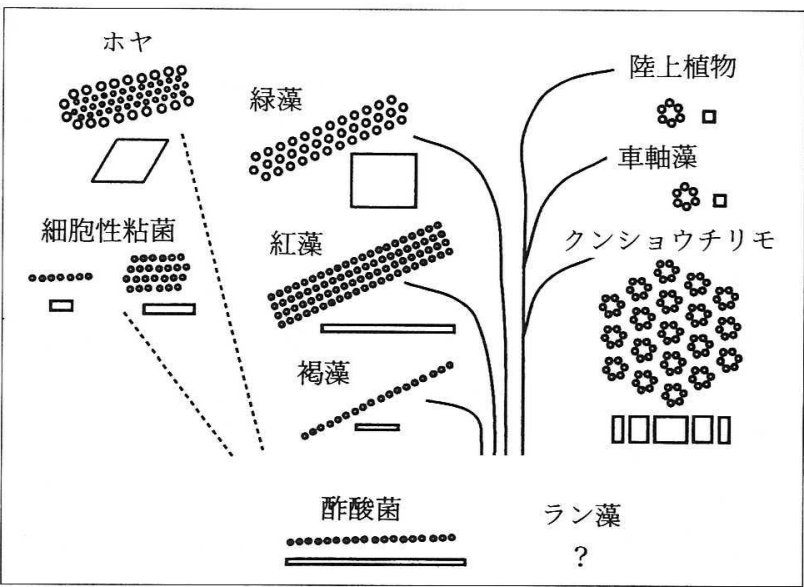

図 2 a TCs とセルロースミクロフィブリルの横断面の形状

TCsの形状はロゼット型と直線型に大きく分けられ, 一般的に直 線型 TCs は太いミクロフィブリルを合成し，単独ロゼット型を有 する高等植物や車軸藻は細いミクロフィブリルを合成する。一方, クンショウチリモなどでは集合したロゼット型 TCs がみられ，こ の場合, ロゼットの数に比例してミクロフィブリルの直径が太くな る. ミクロフィブリルの横断面の形状を TCs の側に示した。ほと んどの生物のミクロフィブリルの横断面は長方形であるが, ホヤは 平行四辺形である。

かどうか不明である。ささに，TCs は細胞側へ深く篞ん ていて,大小 2 種類の顆粒で構成されているという点で, これまでにない新しいタイプの TCsといえよう.

TCs は原形質膜の内側（細胞側）の割断面（protoplasmic fracture face $=\mathrm{PF}$ 面）にのみ存在しているの に対し, 外側の割断面 (exoplasmic fracture face $=\mathrm{EF}$ 面）では PF 面の TCs と相補的な凸状の膜構造が観察さ れた。すなわち，ホヤの TCs は PF 面に親和性の高い膜 顆粒から構成されているか, または細胞質側と何らかの つながりがあることが何える。またいくつかの TCsで は, 窪みの部分がアモルファス状物質で満たされており, そこから連続的にミクロフィブリルが伸びだしていた (図 1)。つまり，アモルファス状物質は結晶化する直前 のセルロースであろうと考えられる。これまで多くの生 物で TCsが観察されているが, TCs とミクロフィブリ ルとが直接結びついた例は今回が初めてであり，TCs が ミクロフィブリル合成装置であることを裏付けている。

天然セルロースはセルロースの I 〜 IVの 4 つの結晶形 態のうち $\mathrm{I}$ 型を有し, $\mathrm{I}_{\alpha}$ (三斜晶) と $\mathrm{I}_{\beta}$ (単斜晶) の複合 結晶であることが知られている ${ }^{(7)}$. そして，この $\alpha$ と $\beta$ の比率にも前述の TCs の形状の違いの関与が指摘され ている ${ }^{(8)}$. 図 2 は, ホヤも含めて現在明らかになってい る生物の TCs の形状と合成されるセルロースミクロフ 
イブリルの形態を示したものである. TCs の形状は直線 型とロゼット型の 2 種に分けられ，一般に直線型のほう が太く高結晶性のミクロフィブリルを合成する. また直 線型 TCs は $\mathrm{I}_{\alpha}$ に富んだセルロースを合成し，ロゼット 型は $\mathrm{I}_{\beta}$ 型を合成することが知られている. ホヤの TCs を直線型かロゼット型かに分けるとすれば前者に該当す るが, 実はホヤの作るセルロースは純粋な $\mathrm{I}_{\beta}$ 型である. したがって，ホヤの TCs は直線型であるにもかかわら ず $\mathrm{I}_{\beta}$ 型のセルロースを合成するのである.

$\mathrm{TCs}$ の形状とセルロースミクロフィブリルの結晶形 態との関係はこれまで考えられたほど単純なものではな いらしい. セルロースが結晶化するときの外部の環境, たとえば成長に伴って発生する応力によって変化すると いう報告(9) もあるが, 他のマトリックスや膨圧などに影 響されるのかも知れない。その一方で, 合成酵素の空間 的配置がセルロースの結晶形態に何らかの影響を与える ことも十分考えられる. 今後, さらに高分解能の電顕手 法を駆使してホヤの TCs の形状を詳細に観察するとと

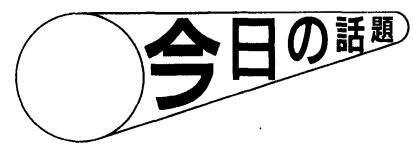

もに，ホヤでしばしば観察されるアモルファス状セルロ 一スの超微細構造を明らかにすることにより，ミクロフ イブリル結晶化の機構を解明する必要があるだろう. 最 後に, 動物で唯一七ルロースを生産するホヤのセルロー ス合成能が進化の過程でどのように受け継がれてきたの かは, とりわけ興味深い課題である.

1) P.A. Richmond: $i n$ "Biosynthesis and Biodegration of Cellulose", ed. by C.H. Haigler and P.J. Weimer, Marcel Dekker Inc., 1991, p. 5.

2) S. Kuga \& R.M. Brown, Jr. : in "Cellulose and Woodchemistry and Technology", ed. by C. Schuerch, John Wiley \& Sons Inc., 1989, p. 677.

3）伊東隆夫：瀻維学会誌，1, 20 (1997).

4) S. Kimura \& T. Itoh : Protoplasma, 194, 151 (1996).

5）木村 聡, 伊東隆夫：電子顕微鏡, 1, 59 (1996).

6) S. Kimura \& T. Itoh : Protoplasma, 186, 24 (1995).

7) R.H. Atalla \& D.L. Vanderhart: Science, 223, 283 (1984).

8) M. Wada, J. Sugiyama \& T. Okano: 木材学会誌, 41, 186 (1995).

9) Y. Kataoka \& T. Kondo: Macromolecules, 29, 6356 (1996).

(伊東隆夫, 木村 聡, 京都大学木質科学研究所)

\section{サトウキビ茎葉での窒素固定}

\section{高い寄与率に注目. 根粒形成とは別のシステムとして期待}

これまでイネ, トウモロコシ, ソルガムなどの非マメ 科作物と根圈微生物による協同的窒素固定について長い 間研究が進められてきた。土㙵中で単独で窒素固定する Azotobacter P Clostridium よりも根圈で根から炭水 化物などエネルギー源を得ることができる窒素固定微生 物 Azospirillum や Klebsiella は, マメ科植物の根粒に 相似の部分をもつシステムを作っている. 事実, 多くの 非マメ科作物の根圈の窒素固定活性は, 非根圏よりも高 く, また固定された窒素が, 作物に利用されている. 特 に水田のイネの根圏は, ニトロゲナーゼ反応に阻害とな る酸素ガスが少なく, アンモニウム濃度も低く, 根粒に よく似た環境が作られている.

このように根圈の窒素固定は, 根粒に似たシステムと なっているが, 根粒とは違った点もある. たとえば, 根 粒では窒素固定微生物は根の細胞の中に入っており, 植 物から炭水化物などのエネルギー源を直接受けとること ができるのに対し, 根圈システムでは窒素固定微生物は 多くの場合, 根から少し離れた部位や根の表面にすみつ
いていて, 窒素固定以外の菌が多くすみついているこの 部位では，根から放出されるエネルギー源を競争し合っ て利用することになる. また, 根粒では微生物が固定し た窒素は, アンモニアからアミノ酸やウレイドに変換さ れ，ただちに植物へ移行する体制ができており，固定し た窒素の $95 \%$ が短時間にホスト植物に利用される。圃場 に生育する根粒形成植物の場合, 生長に必要な窒素の 45〜90\%が固定窒素起源となる.一方, 根圏の窒素固定 システムでは, 微生物が固定した窒素は微生物の分解に よって周辺に放出され, その 10〜20\%の窒素が作物に吸 収される. 固場では作物への根圈固定窒素の寄与は, 作 物の必要窒素のせいぜい $2 \sim 5 \%$ と推定される.

サトゥキビの根圈からも1950年代から, Beijerinckia, Azospirillum, Enterobacter, Erwinia, Azotobacter, Derxia などの窒素固定菌が単離されてきた。特にブラ ジルでは, 肥料を少なくしてサトウキビを栽培できるこ とから, 多くの研究が続けられてきた.この研究のリー ダーである Döbereiner 博士らは, 最近サトウキビの茥 


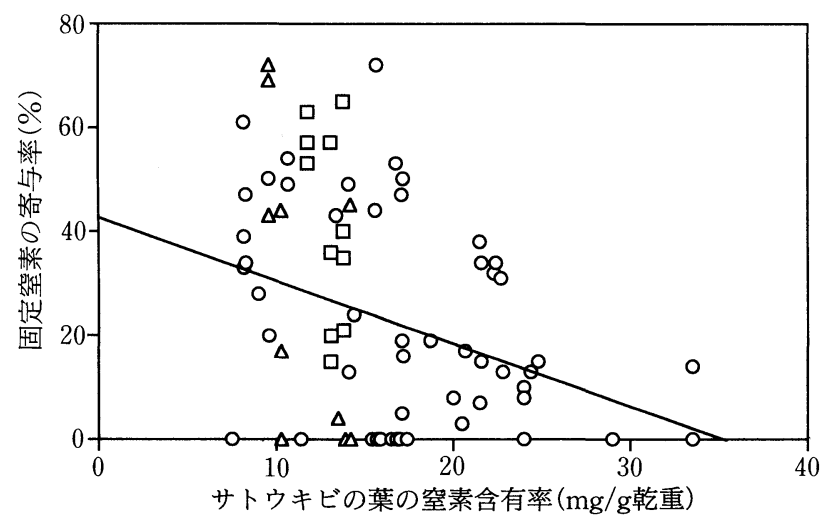

図 1 -サトウキビの葉の窒素含有率と固定窒素の寄与率

$\bigcirc:$ ブラジル, $\triangle:$ フィリピン $\square:$ 宮古島

や葉から新しい窒素固定微生物 Acetobacter diazotrophicus や Herbaspirillum spp. を発見した ${ }^{(1)}$. A. diazotrophicus はオーストラリア, メキシコ, ギニアのサトウ キビでもその存在が確認された。また，サトウキビ以外 のサツマイモ, キャッサバの茎葉からも単離されている. これらの作物は少肥料で生育がよく，施肥した以上の窒 素を吸収することで知られている。

A. diazotrophicus は, 高糖 $(10 \%)$ の溶液での生育が 良く，有機酸を生産する。また，低 $\mathrm{pH}$ や酸素ガスの存 在下でも窒素を固定し, 硝酸還元酵素活性がなく, 硝酸 による窒素固定活性の阻害もないとされている。この菌 は土壤中に生息せず，植物の通導管付近や茎葉の細胞間 アポプラストにコロニーをつくる。このことは，根粒菌 や根圈窒素固定微生物が土壇を媒介として伝搬されるの に対して，A. diazotrophicus では栄養体により伝わる ことを示すと考えられ，サトウキビでは茥，サツマイモ， キャッサバではイモにより, 次世代の植物に伝搬すると 予想される。

サトウキビの窒素固定量は，ポットやコンクリート枠 で ${ }^{15} \mathrm{~N}$ 標識の肥料を施用して栽培することで推定されて いる ${ }^{(2)}$.ポット実験ではブラジル栽培品種 CB47-89 でそ

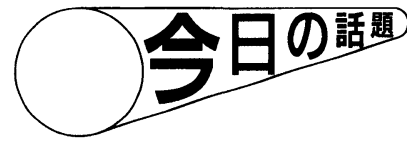

の植物窒素の $60 \%$ \%゙，また 10 品種を用いたコンクリー 卜枠実験では $70 \%$ までが生物的窒素固定によるものと 推定された。 ${ }^{15} \mathrm{~N}$ 自然存在比を用いた推定法により,ブラ ジル，フィリピン，宮古島(日本)の各地の固場で栽培さ れたサトウキビについて, 植物窒素への固定窒素の寄与 率を調べた筆者らの結果によると，ブラジルでは地域に よっては平均 $30 \%$ （0～72\%の変異）の寄与率が，フィ リピンでは 1 個所，宮古島では調べた 3 個所すべてで高 い有意な寄与率が推定された ${ }^{(3)}$.さらに, サトウキビの葉 の窒素含有率と窒素固定の寄与率の関係をみると, 図 1 に示すように，葉の含有率が低い状況で窒素固定の見か けの寄与率は大きくみえる，肥料窒素の少ない生育後期 の糖の集積時期に窒素固定菌の活性が明らかになると言 えよう。また，日本のサッマイモについても，窒素固定 の有意な寄与が認められている(未発表).

根圈の窒素固定は多くの場合，その固定量は少なく， また植物への寄与も小さい。これに対し，サトウキビ， サツマイモの茎葉部では上記のように窒素固定の寄与は $30 \%$ 程度と推定され，これは茎葉部にコロナイズした A. diazotrophicus などの菌によるものと考えられる.茎 葉部では, 糖などの炭水化物は細菌の周辺に多量に存在 し，競合する菌もほとんどなく，肥料や土壌窒素の供給 の少ない生育後期にはよい窒素固定環境ができるとみら れる，もし以上のことが事実であれば，栄養体で繁殖し ない作物についても茎葉窒素固定菌を活発にする工夫を してみることも，非マメ科作物に根粒を形成させ窒素固 定を期待する以前にできる有益な技術であると言えよ う.

1) V.A. Cavalcante \& J. Döbereiner : Plant and Soil, 108, 23 (1988).

2) E. Lima, R.M. Boddey \& J. Döbereiner : Soil Biol. Biochem., 19, 167 (1987); S. Urquiaga, K.H.S. Cruz \& R.M. Boddey : Soil Sci. Am. J., 56, 105 (1992).

3) T. Yoneyama, T. Muraoka, T.H. Kim, E.V. Dacanay \& Y. Nakanishi : Plant and Soil, in press (1977).

(米山忠克, 農林水産省農業研究センター)

\section{サポニンがタンパク質の機能を変える}

\section{高次構造，熱安定性などが变動. 生理機能にも関与か}

サポニンとは植物界に広く存在する配糖体の一種で, 一般的には非糖鎖部分のアグリコンを炭素数 27 のステ
ロイドあるいは炭素数 30 のトリテルペンとしている.こ のアグリコン部分は疎水性であるのに対し糖鎖部分は親 


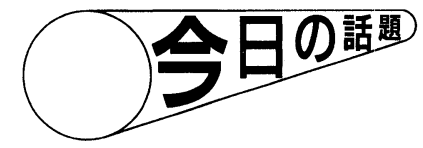

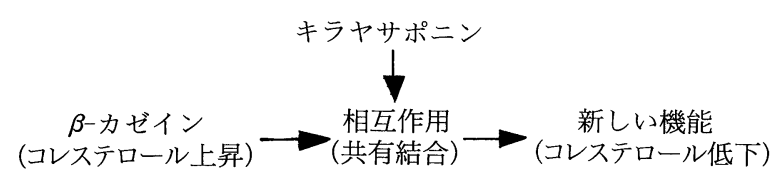

図 1 ロサポニンのタンパク質との相互作用を介した機能

水性であるため, 高い界面活性能をもつことがサポニン 分子の特徴である. 抗コレステロール, 抗脂血, 抗卜ロ ンビン, 抗酸化, 酵素活性阻害などの生理作用をもつこ とが広く知られており, 食品機能の面からもサポニンは 注目されている。

最近，こうしたサポニンのうちシャボンの木 (soap tree)からとれるキラヤサポニンの生理作用について興 味深い報告が出された。すなわち，カゼインにキラヤサ ポニンを添加した食餌をオスのアレチネズミ(Meriones unguiculates)に与えると血清中の LDL（低密度リポ夕 ンパク質）濃度低下がみられるが，この現象について， Potter らは次のような検討を行なっている(1).カゼイン,

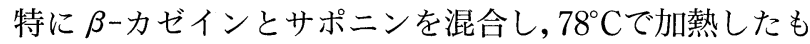
のを電気泳動で調べてみると, 加熱時間の経過とともに 様々な高分子量成分のバンドが生成する。これはタンパ ク質分子が会合していることを示すものであり, 同時に 遊離のアミノ基の減少がみられた。これらの結果より, キラヤサポニンはカゼインと共有結合しているものと推 測され, Potter らはサポニンがコレステロールを低下さ せるメカニズムの一つとして, サポニンとタンパク質と の共有結合を含めたこの相互作用が関与している可能性 を提唱している（図 1).

筆者らは以前より，大豆水抽出画分においてサポニン がタンパク質に強い親和性を示す現象について興味をも ってきた。大豆には soyasapogenol をアグリコンとす る数種のサポニンが含まれておりり年，最近ではさらに $\mathrm{DDMP}^{*}$-サポニンと呼ばれるサポニンも単離されてい $る^{(3)}$. 大豆サポニンにおいても血中脂質濃度の低下, 抗 トロンビン, 抗ウイルス, 抗酸化などの生理作用が報告 されている．大豆サポニンはどのような影響をタンパク 質に及ぼしているのであろうか.

まずウシ血清アルブミン（BSA）をタンパク質試料と して用いることとした ${ }^{(4)}$. BSA は血液中で様々な物質の

*2,3-dihydro-2,5-dihydroxy-6-methyl-4H-pyran-4-one
輸送に関与しているタンパク質で，特に脂肪酸などの疎 水性化合物に対して親和性をもっていることが知られて おり，モデルタンパク質として適しているものと考え る.ただし，この実験ではPotter らの系とは異なり，最 初の段階で加熱処理は行なわず，疎水的相互作用など非 共有結合以外の相互作用を想定している.

サポニンを添加した BSA の変化として, 高次構造の 変化が考えられるが, CD スペクトルや ELISA(酵素免 疫測定法)による抗体反応性についての検討の結果, サポ ニンの添加によっても高次構造にはほとんど影響ないも のと考えられた。一方, サポニン添加 BSA を加熱処理 した後に同様に CD スペクトルや抗体反応性を測定した ところ, スペクトル変化や抗体反応性低下の開始温度が 約 $20^{\circ} \mathrm{C}$ ほど上昇し, サポニンの添加によって BSA 分子 の熱安定性の高まっていることが示された.

サポニン添加 BSA はトリプシン，キモトリプシンな どのプロテアーゼで処理すると, BSA 単独の場合より も分解率は低下することから, サポニンは BSA の酵素 分解を受けにくくする働きを有することがわかる．さら に，サポニンのグルクロン酸残基をメチルエステル化す ると, 分解率の低下は半分ほどとなり, サポニンの負電 荷も相互作用に重要であるものと推測される.

大豆グロブリン画分や大豆トリプシンインヒビターに サポニンを添加してその影響をみた実験では, BSAの 場合とは異なりタンパク質の高次構造変化がみられ, 夕 ンパク質によって応答の異なることが示された ${ }^{(5)}$.さら に, プロテアーゼ処理分解物の分析データや化学修飾し たサポニンを用いた相互作用実験のデー夕を考え合わせ ると，サポニンはタンパク質のどこにでも親和性を示す というものではなくて，ある程度特異的な作用部位をも っているものと予想されるが, 詳細はまだわかっていな い.

従来，サポニンの生理的な機能についてはサポニンの 構造面ばかりが強調されてきた。しかし, 血中コレステ ロール低下作用のようにサポニンのみあるいは夕ンパク 質のみでクリアな説明のできていない現象も多く，ここ に述べてきたような成分間の相互作用を介して発現する 部分が従来の予想以上に多いのではないかと考えられ る. 今後, 食品の機能について考慮する際には, この点 を充分に検討する必要があろう。

1) S.M. Potter, R. Jimenez-Flores, J. Pollack, T.A. Lone \& M.D. Berber-Jimenez: J. Agric. Food Chem., 41, 1287 
(1993).

2) 下山田真, 塚本知玄, 大久保一良：化学と生物, 29, 213 (1991).

3) S. Kudou, M. Tonomura, C. Tsukamoto, M. Shimoyamada, T. Uchida \& K. Okubo: Biosci. Biotech. Biochem., 56, 142 (1992).

4) S. Ikedo, M. Shimoyamada \& K. Watanabe : J. Agric.

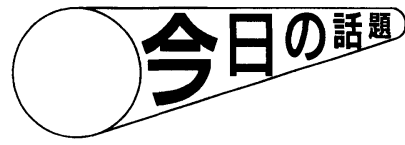

Food Chem., 44, 792 (1996).

5) M. Shimoyamada, R. Ootsubo \& K. Watanabe : Proceedings of 7th International Congress of Food and Engineering, A25 (1997).

(下山田 真, 岐阜大学農学部)

\section{Ri プラスミドT-DNA の挿入を受けたタバコ属植物 植物病原細菌之宿主の進化を辿れるか?}

生物は，各々の個体の周辺に存在する他の個体あるい は生物と無関係に生息することはできない. 自己を優先 させ，さらにその子孫を残すべく，相互に競争しあい， 勝者のみが生き残れる，中には他を積極的に利用して競 争に勝とうとする生物がおり，これに抵抗していく生物 がいる，寄生者と宿主とは，まさにこの関係にあり，特 に病原菌と宿主の競争は，この関係ができた当初から 延々と繰り広げられた壮絶なバトルである.人類はこの 中で，抗生物質をはじめとする医薬品を産みだし，近 年, 病原菌のうち細菌による感染症にほぼ打ち勝ったと 考えた。 その逆襲からか, 昨年は病原性大腸菌 O-157 に よる食中毒が日本中を震撼させ, 今年もその襲撃に予断 を許さない.

植物にも病原菌による感染症があり, 系状菌やウイル ス，細菌による病気が多大な被害をもたらしている。根 頭癌腫病は土袞細菌 Agrobacterium tumefaciens によ る病気として，バラをはじめ園芸作物に被害を与えてい るが，本菌は植物の宿主一ベクター系として有用なため， 植物分子生物学の若い研究者には, その実体が植物病原 菌という意識が薄らいでいるのではあるまいか. $A$. tumefaciens は巨大プラスミドを保有し，その一部（TDNA) が菌の中で切り出され, 植物細胞に移行し染色体 に挿入される．T-DNA 上には植物ホルモン生合成遺伝 子群などがコードされており，これらの植物細胞内での 発現により癌腫が形成される。同属の土壌細菌には毛根 病菌 A. rhizogenes が存在し, 本菌も植物に毛状根とい う一種の癌腫を形成させる. 毛状根は植物で有用二次代 謝産物を生産させる器官培養の材料としてご存知の方が 多いかも知れない。

筆者らは，日本 (千葉県) で単離されたメロン毛根病 菌 A. rhizogenes MAFF301724 株を植物形質転換用 の宿主一ベクター系として利用するため, 本菌の毛状根を
誘発する Ri プラスミド (pRi1724)の解析を進めてきた。 特に，T-DNA 上の毛状根を誘発する遺伝子群 $(r o l)$ を 含む塩基配列の決定を行なってきた ${ }^{(1)}$ が, 最近, T-DNA が切り出される境界領域 (RB) 付近の塩基配列を決定し, 他の Ri プラスミド T-DNA（pRiA4 や pRi8196）とはま ったく相同性のないタンパク質コード領域 (ORF X) を 見いだした。この配列を用いて，DNA データベースで相 同性検索を行なったところ，キダチタバコ（Nicotiana glauca)の染色体中に存在し, Ri プラスミド T-DNAの 一部と高い相同性を示す cellular T-DNA（cT-DNA） のみにヒットした。

cT-DNA は N. glauca より初めて見いだされ(2)，その 後, 64 種以上ある夕バコ属植物の少なくとも 6 種に存在 すると報告されている(3). Ri プラスミド T-DNA の rol 遺伝子群を含む配列の一部は，この cT-DNA に高度に 保存されており，不完全な逆向き構造 (left arm と right arm）を形成している(図 1)。また，cT-DNA の rol 遺 伝子群は偽遺伝子と考えられてきたが，N. langsdorffi と N. glauca の雑種より形成される遺伝的腫瘍内で転 写されていたこと ${ }^{(4,5)}$ から, 腫瘍形成との関連が示唆さ れた。さらに, N. tabacum でも cT-DNA の一部( rolC 遺伝子）が単離され，転写が若い葉の中で行なわれてい ることが報告されている(6).

以上のことから, 一部のタバコ属の祖先植物に Ri プ ラスミド T-DNA が挿入されたことが想像されるが, cT-DNA と夕バコ染色体 DNA の境界が明らかでなか ったため，起源となる T-DNA は謎であった。

筆者らは，この詳細を調べるため，N. glauca 染色体 より cT-DNA の left arm 上の相同領域を単離し，塩基 配列を決定した ${ }^{(7)}$. 図 1 に示すように, pRi1724 T-DNA 上に存在する新規 ORF X と相同な配列を見いだした が，この ORF は途中に終止コドンがあり，2つに分断さ 

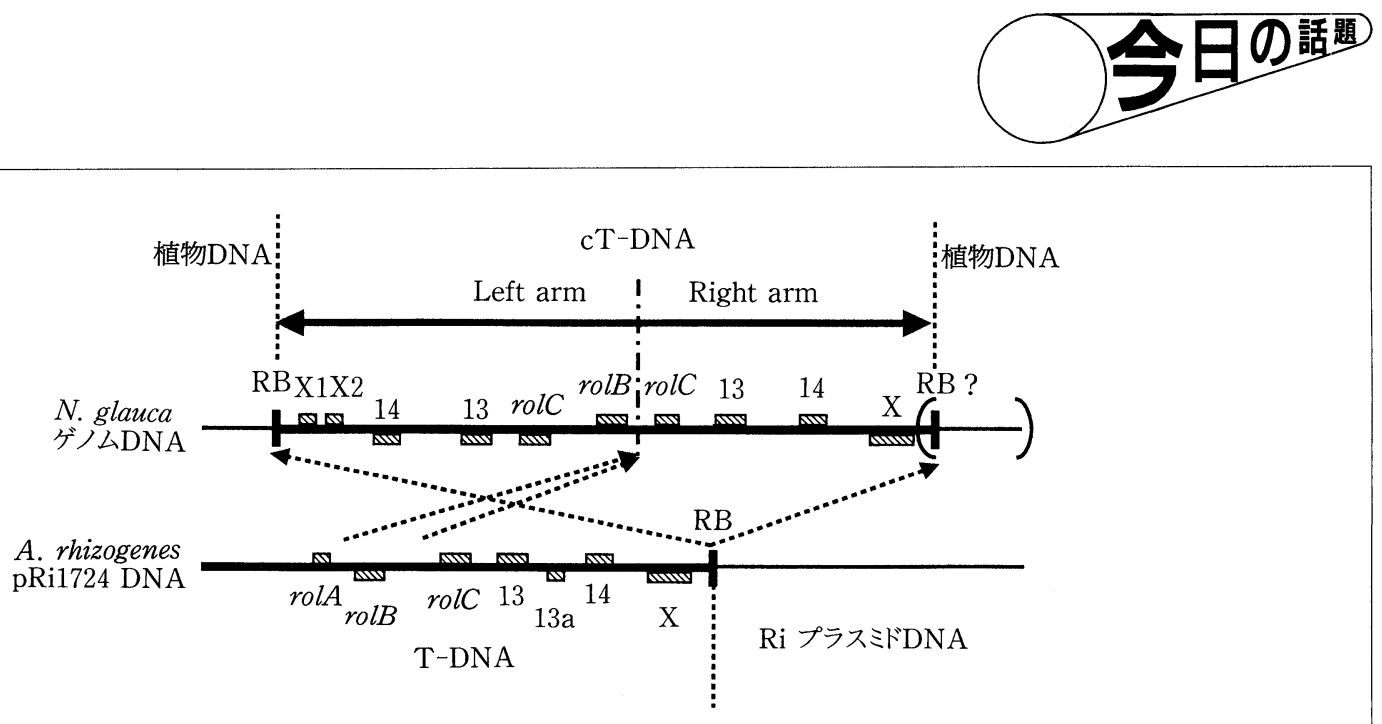

図 1 - cT-DNA の構造

れていた(ORF X1，X2)。興味あることに，相同性のあ る領域は pRi1724 T-DNAの RB から消失した ${ }^{(7)}$ 。これ らの事実は, pRi1724 T-DNA 様配列が cT-DNA の起 源である可能性を示すものであるが，これだけでは証拠 不十分であるので，現在 right arm 上の相当配列を単離 し，塩基配列を決定中である。もし，right arm からも 同様な結果が得られれば，pRi1724 T-DNA 様配列が cT-DNA の起源となった可能性が濃厚となる.

最近，植物の 1 本鎖 DNA ウイルス gemini virus DNA の一部と相同な配列が夕バコ染色体中に高度な繰 り返し構造として見いだされている ${ }^{(8)}$.しかし,植物染色 体で cT-DNA ほどはっきりと起源のわかる外来 DNA の挿入は類を見ない. タバコ属植物は rustica, tabacum および petunioides という 3 つの亜属よりなり，cTDNA は rustica および tabacum 亜属の少なくとも 6 種に見いだされている. cT-DNA の挿入は, rustica お よび tabacum 亜属が分岐する以前で，かつこれらの祖 先と petunioides 亜属の祖先植物が分岐した後に生じた と考えられる.このとき，すでに Ri プラスミドが夕バコ に毛根病を発生させ，現在に至るまでその関係は継続し ていることになる。一方，Ri プラスミドは，T-DNAの うち rol 遺伝子群を含む領域の保存性のみが高い. pRi1724 T-DNA がcT-DNA の起源ならば，そのとき， Ri プラスミド T-DNA はどのような形態であったので あろうか.もしかすると，pRi1724 は Ri プラスミドのき わめて古い夕イプのものなのかもしれない.

筆者らは, N. tabacum にも pRi1724 T-DNA の新規

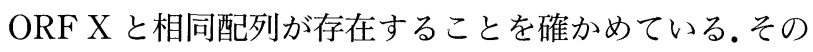

他の夕バコ属植物についても存在を調べる予定で, これ らの塩基配列の解析より, cT-DNA を基にしたタバコ属 植物種の系統樹の一部を描けるものと考えている.一方, 動物, 植物とも外来 DNA の挿入位置はランダムとされ てきたが, 最近 T-DNA はクロマチン構造をとらない DNA 領域，すなわち scaffold あるいは matrix attachment region (SAR/MAR) ${ }^{(9)}$ の近傍に挿入される可能性 が報告されている(10).これが事実なら, 幾つかの夕バコ 属植物種において, cT-DNAの RB の外側に存在する本 来の夕バコ染色体 DNA 領域を調べることにより, 外来 DNA が挿入される領域の変化を追いかけることができ ないであろうか.これによって，ほんの一部ではあるが 外来 DNA 挿入による染色体 DNA の構造変化を垣間み ることができるのではないかと考えている.

さて, 南米原産といわれる夕バコ属植物と日本で発見 された Ri プラスミド T-DNA の相同性が高いというの は，いかなる理由によるものであろうか.

1) N. Tanaka, T. Ikeda \& A. Oka : Biosci. Biotech. Biochem., 58, 548 (1994).

2) F.F. White, D.J. Garfinkel, G.A. Huffman, M.P.Gordon \& E.W. Nester : Nature, 301, 348 (1983).

3) I.J. Furner, G.A. Huffman, R.M. Amashino, D.J. Garfinkel, M.P. Gordon \& E.W. Nester : Nature, 319, 422 (1986).

4) T. Ichikawa, Y. Ozeki \& K. Syono: Mol. Gen. Genet., 220, 177 (1990).

5) S. Aoki, A. Kawaoka, M. Sekine, T. Ichikawa, T. Fujita, A. Shinmyo \& K. Syono: Mol. Gen. Genet., 243, 706 (1994).

6) A.D. Meyer, T. Ichikawa \& F. Meins, Jr.: Mol. Gen. Genet., 249, 265 (1995).

7) 田中伸和, 山下一郎：第 69 回日本生化学会大会·第 19 回日本 
分子生物学会年会 (札幌) 合同年会講演要旨集, 744 (1996).

8) E.R. Bejarano, A. Khashoggi, M. Witty \& C. Lichtnestein : Proc. Natl. Acad. Sci. USA, 93, 759 (1996).

9) 筒井 研：実験医学, 13, 1343 (1995).

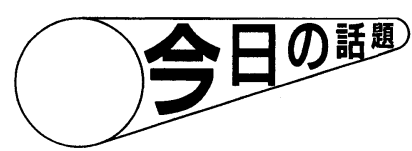

10) A. Dietz, V. Kay, T. Schlake, J. Lamdsmann \& J. Bode : Nucleic Acids Res., 22, 2744 (1994).

(田中伸和，広島大学遺伝子実験施設)

\section{プロフィル}

伊東 隆夫（Takao Itoh） 昭和 17 年 4 月 5 日生 $<$ 略歴 $>1968$ 年京都大学大学 院農学研究科修士課程修了/同年同大学 木材研究所助手 / 1979 年同助教授 / 1990 年同教授 $/ 1991$ 年改組により同大 学木質科学研究所教授, 現在にいたる <研究テーマと抱負 > 進化に伴う細胞壁 の発達 $<$ 趣味 $>$ テニス

五十嵐一衛（Kazuei Igarashi） 昭和 16 年 7 月 7 日生 $<$ 略歴 $>$ 昭和 39 年千葉大 学薬学部卒業 $/ 41$ 年同大学大学院薬学 研究科修士課程修了/ 44 年大阪大学微 生物病研究所研究生 $/ 45$ 年千葉大学薬 学部教務員 $/ 50$ 年同講師 $/ 54$ 年同助教 授 $/ 59$ 年同生物活性研究所教授 $/ 61$ 年 同薬学部教授, 現在にいたる。この間, 41〜43 年米国ペンシルバニア大学医学 部 Kaji 研究室留学<研究テーマと抱 負>ポリアミンの機能を明らかにするこ と<趣味 $>$ 推理小説乱読, 小旅行

石渡 裕 (Yutaka Ishiwatari) 昭和 45 年 3 月 23 日生 $<$ 略歴 $>1992$ 年東京大 学農学部農芸化学科卒業/1997 年同大 学大学院農学生命科学研究科博士課程修 了/同年(株)味の素入社, 現在にいた る<趣味 $>$ 競馬観戦, 飲酒, 横浜ベイス ターズの応援

近江谷克裕（Yoshihiro Ohmiya）昭和 35 年 2 月 23 日生 $<$ 略歴 $>$ 平成 2 年群馬 大学大学院医学研究科博士課程修了/同 年(財) 大阪バイオサイエンス研究所特別 研究員 $/ 4$ 年新技術事業団「さきがけ研 究 $21 」$ 研究員 $/ 7$ 年理化学研究所協力研 究員 $/ 8$ 年静岡大学教育学部助教授, 現 在にいたるく研究テーマと抱負 > 新規生
物発光系の探索およびその解明. さらに は，ルシフェリン合成系を含むトータル な生物発光システムの解明 $<$ 趣味 $>$ 日本 酒, 旅, 歴史小説

柏木 敬子 (Keiko Kashiwagi) 昭和 30 年 11 月 28 日生 $<$ 略歴>昭和 53 年千 葉大学薬学部薬学科卒業 $/ 55$ 年同大学 大学院薬学研究科修士課程修了/同年大 正製薬(株)総合研究所勤務 $/ 59$ 年千葉 大学生物活性研究所助手 $/ 62$ 年同薬学 部助手，現在にいたる。この間，63〜 64 年米国 NIH Tabor 研究室留学<研究テ ーマと抱負>ポリアミンの生理作用およ び細胞内濃度調節機序 $<$ 趣味 $>$ 読書

木下 英司（Eiji Kinoshita）昭和 43 年 9 月 1 日生 $<$ 略歴 $>$ 平成 4 年愛知教育 大学教育学部総合科学課程卒業/同年広 島大学大学院生物圏科学研究科博士前期 課程修了 $/ 9$ 年ラホヤ・アレルギー免疫 学研究所ポストドクトラルフェロー, 現 在にいたる<研究テーマと抱負＞癌やア レルギーの発症に関わる細胞内シグナル 伝達機構の総括的解明 $<$ 趣味 $>$ 夏はテニ ス，冬はスキー

木 村 聡 (Satoshi Kimura) 昭和 42 年 9 月 20 日生 $<$ 略歴 $>1991$ 年高知大学 理学部生物学科卒業/1993 年同大学大 学院理学研究科生物学専攻修士課程修 了/同年京都大学大学院農学研究科博士 後期課程編入学, 現在にいたるく研究テ ーマと抱負>セルロースミクロフィブリ ルの形成と配向制御の仕組み<趣味>酒

清野 宏 (Hiroshi Kiyono) 昭和 28 年 3 月 17 日生 $<$ 略歴 $>$ 昭和 52 年日本大
学松戸歯学部歯学科卒業 / 55 年米国ア ラバマ大学バーミングハム校医学系大学 院入学 $/ 58$ 年同博士課程修了 $/ 59$ 年同 研究・臨床助教授 $/ 61$ 年ドイツ・マック スプランク生物学研究所上級研究員 $/ 63$ 年米国アラバマ大学バーミングハム校 AIDS 研究センター主任研究員/平成元 年同準教授 $/ 3$ 年同教授 $/ 6$ 年大阪大学 微生物病研究所教授, 現在にいたるく研 究テーマと抱負 $>$ 粘膜免疫 $<$ 趣味 $>$ ゴル ᄀ

窪 田 満（Mitsuru Kubota）昭和 37 年 2 月 19 日生 $<$ 略歴 $>$ 昭和 61 年北 海道大学医学部医学科卒業／同年日本赤 十字社医療センター研修医 $/ 63$ 年北海 道大学医学部小児科および関連病院にて 研修/平成 5 年東北大学医学部第 2 病理 所属 $/ 7$ 年米国アラバマ大学バーミング 八厶校留学 $/ 8$ 年北海道大学医学部小児 科勤務, 現在にいたるく研究テーマと抱 負 $>$ 小览消化管の免疫学的発達の解明 と, その過程における異常の表われとし ての食物アレルギーや遷延性の下痢病の 研究.さらに，小児期の粘膜免疫の基礎 に基づいた新しい粘膜ワクチンの開発 く趣味＞アウトドアライフ（とにかく外 で遊ぶこと）

熊谷 英彦 (Hidehiko Kumagai) 昭和 15 年 10 月 30 日生 $<$ 略歴 $>$ 昭和 39 年京 都大学農学部農芸化学科卒業 $/ 44$ 年同 大学大学院農学研究科博士課程修了/同 年同大学食糧科学研究所助手 $/ 52$ 年同 農学部食品工学科助教授 /平成 3 年同教 授, 現在にいたるく研究テーマと抱負 $>$ 微生物酵素の構造と機能, その応用 $<$ 趣 味>ゴルフ 